Original Article

\title{
PHARMACEAUTICAL CARE IMPROVED THE QUALITY OF LIFE OF PATIENT WITH HEMODIALYSIS
}

\author{
ASYRUN ALKHAIRI LUBIS*, AZIZAH NASUTION, ROSIDAH \\ Departemen of Pharmacology, Faculty of Pharmacy, Sumatera Utara University Rasyida Kidney Hospital, Medan, Indonesia \\ Email: asyrun.lubis@gmail.com
}

Received: 08 Aug 2019, Revised and Accepted: 10 Oct 2019

\section{ABSTRACT}

Objective: Patients undergoing hemodialysis in the long term often experience complications that affect the quality of life (QOL) of the patients. Comprehensive health services are very important for improving the QOL of the patients with chronic renal failure undergoing hemodialysis. The purpose of this study was to prove that the provision of therapy with pharmaceutical care can improve the QOL of hemodialysis patients.

Methods: This research was a quasi-experimental study pre and post test design. Samples were recruited applying the purposive sampling method. As many as 50 patients met the inclusion criteria and were asked to fill out the World Health Organization Quality Of Life (WHOQOL) questionnaire to measure their QOLs before and after the provisions of pharmaceutical care. Data obtained before and after pharmaceutical care were tested using paired t test, person correlation test, and Wilcoxon test in the program of SPSS 19.

Results: The results showed women more often experience complications when hemodialysis (62\%), sex with quality of life ( $p=0.907)$, education with quality of life $(p=0.277)$, work with quality of life $(p=0.582)$ length of undergoing hemodialysis with quality life $(p=0.733)$ no significant effect. Age $(p=0.044)$ significantly influences quality of life. And the average quality of life before administration of pharmacy and care was $48.12 \pm 5.98$, while the quality of life after administration of therapy with pharmaceutical care was $50.16 \pm 6.22$. Based on the Wilcoxon test, this value was significantly different $(\mathrm{p}=0.009)$.

Conclusion: The conclusion of this study is the provision of therapy accompanied by pharmaceutical care significantly improves the quality of life of hemodialysis patients.

Keywords: Quality of life, Hemodialysis, Pharmaceutical care, Hemodialysis complications

(C) 2019 The Authors. Published by Innovare Academic Sciences Pvt Ltd. This is an open access article under the CC BY license (http://creativecommons.org/licenses/by/4.0/) DOI: http://dx.doi.org/10.22159/ijcpr.2019v11i6.36341

\section{INTRODUCTION}

Hemodialysis (HD) is an act to replace some of the kidney function. This action is routinely performed on patients with chronic kidney disease (PGK) or chronic kidney disease (CKD) stadium $\mathrm{V}$ or chronic renal failure (GGK). The action of HD is currently experiencing rapid development, but there are still many sufferers experiencing medical problems while undergoing HD. Acute complications of hemodialysis are defined as the presence of clinical manifestations related to hemodialysis that occur during a dialysis session or in the first $24 \mathrm{~h}$ after dialysis [1].

A complication that often occurs in patients undergoing HD is hemodynamic disorders [2]. Blood pressure generally decreases with ultrafiltration (UF) or withdrawal of fluids during HD. Intradialytic hypotension occurs in $20-30 \%$ of patients undergoing regular HD [3]. A study of patients with regular HD conducted in Denpasar found an incidence of intradialytic hypotension of $19.6 \%$ [4].

Besides hypertension, the problem related to hemodialysis is anemia, as Weiner said that anemia is a common complication in hemodialysis (HD) patients, mainly due to inadequate production of erythropoietin (EPO) due to kidney failure. Management of anemia therapy is important because it can improve patient clinical outcomes. Introduction EPO recombinant human therapy (rhEPO) to treat chronic anemia in kidney disease patients (CKD) by ultimately improving the quality of life of patients [5].

Another complication of concern is arrhythmias associated with hemodialysis, with data reported as $+5 \%-75 \%$. The most common and deadly types of arrhythmias are ventricular and ectopic arrhythmias. The rate of hemodialysis associated with complex ventricular arrhythmias is around $35 \%$ and the second most common type of arrhythmia is atrial fibrillation around 27\% [6]. About $62 \%$ of sudden cardiac deaths are associated with arrhythmia disorders [7].
Cramping complications are also frequently observed in $24 \%-86 \%$ of cases during the first years of dialysis therapy, but data show that only $2 \%$ of patients suffer from cramps zafteessions of hemodialysis in a week [8]. Other common complications include nausea, vomiting with an incidence of $5 \%-15 \%$, headaches with an incidence of 5\%-10\% and itching with an incidence of 5\%-10\% [9].

\section{MATERIALS AND METHODS}

This type of research is a quasi-experimental research with pre and post test design. Using a prospective approach, which is a longitudinal study by following the course of the disease in the order of time [10]. This research was conducted at the Rasyida Kidney Special Hospital in Medan with consideration of the highest number of hemodialysis patients in this hospital among other hemodialysis facilities. This research starts from data retrieval planned for 3 (three) months from May to August 2018.

The inclusion criteria were CKD stage 5D patients, aged 18-80 y, could read, and sign informed consent in Indonesian, willing to sign (informed consent). Exclusion criteria were hemodialysis patients who experienced psychiatric disorders and decreased consciousness.

All patients were given an explanation of the goals, procedures, benefits, and risks of undergoing this study, then agreed to sign an informed consent. Determination of CKD by history, blood lab results, urine and CKD stage are determined by the Cockroft-Gault formula. After ascertaining that the patient met the inclusion criteria, blood pressure measurements were taken before and after $\mathrm{HD}$ and $\mathrm{Hb}$ values.

Do the monitoring for complications that occur. Patients who experience hemodialysis complications are given therapy by a doctor. Patients were given counseling by researchers about the drugs and illnesses suffered, as well as complications that were 
experienced and monitoring improvement in the quality of life experienced by patients during the three weeks of research. Quality of life monitoring is carried out the following month. The results were presented by scoring and transformation of the WHOQOL score was then calculated on average for 4 domains and interpreted using the following criteria:

0-20 = very poor quality of life

$21-40=$ poor quality of life

41-60 = enough quality of life

$61-80$ = good quality of life

$81-100=$ very good quality of life

The collected results are analyzed by the appropriate statistical methods.

\section{RESULTS}

This study proves and answers the researcher's question that is whether the provision of therapy accompanied by pharmaceutical care is related to the quality of life of patients with stage 5 kidney failure who experience complications during hemodialysis at Rasyida Kidney Hospital in Medan.

\section{Sample characteristics}

The sample in this study were patients with chronic kidney failure who were affected by complications while undergoing hemodialysis as many as 50 people.

Table 1 shows the quality of life of patients in this study tended to the quality of life of 44 people, with a good quality of life of 4 people and with a poor quality of life of 2 people. The categories of patients' quality of life were very good and very poor were not included in this study.

Table 1: Distribution of patients based on quality of life

\begin{tabular}{lll}
\hline Quality of life characteristics & Frequency & Percentage \\
\hline Poor & 2 & 4 \\
Enough & 44 & 88 \\
Good & 4 & 8 \\
\hline
\end{tabular}

Table 2 shows the samples studied were patients with an average age of $54.90 \pm 12.1 \mathrm{y}$ with the youngest age being $18 \mathrm{y}$ and the oldest being $73 \mathrm{y}$. The highest age range is found at the age of $51-60 \mathrm{y}$ which is equal to $36 \%$.

Table 2: Distribution of patients by age

\begin{tabular}{llll}
\hline No & Age category (Year) & Amount & Percentage (\%) \\
\hline 1 & $0-10$ & 0 & 0 \\
2 & $11-20$ & 1 & 2 \\
3 & $21-30$ & 2 & 4 \\
4 & $31-40$ & 2 & 4 \\
5 & $41-50$ & 8 & 16 \\
6 & $51-60$ & 18 & 36 \\
7 & $61-70$ & 14 & 24 \\
8 & $<80$ & 5 & 10 \\
\hline
\end{tabular}

Table 3 below shows the characteristics of the sample by sex, the number of female samples is more that 31 people (62\%) and 19 men (38\%), there are very large differences in the number of samples between men and women.

Table 3: Distribution of patients by gender

\begin{tabular}{lll}
\hline Sex characteristics & Frequency & Percentage \\
\hline Man & 19 & 38 \\
Women & 31 & 62 \\
\hline
\end{tabular}

Table 4 below shows the characteristics of patients based on education, the highest number of patients, namely at the bachelor level as many as 22 people (44\%), then in patients who have junior high school education as many as 12 people $(24 \%)$ and at the level of high school education (high school) also as many as 9 people $(18 \%)$. At the elementary school level (Elementary School) as many as 6 people (12\%), and the fewest number is at the level of nonschool as much as 1 person $(2 \%)$.

Table 4: Distribution of patients based on their most recent education

\begin{tabular}{lll}
\hline Latest educational characteristics & Frequency & Percentage \\
\hline No Education & 1 & 2 \\
Elementary School & 6 & 12 \\
Junior High School & 12 & 24 \\
Senior High School & 9 & 18 \\
Bachelor & 22 & 44 \\
\hline
\end{tabular}

Table 5 below shows the characteristics of patients based on work namely not working as many as 13 people (26\%), working as private employees as many as 21 people (41\%), public servants as many as 6 people (6\%) and as many as 13 people working as entrepreneurs (26) \%).

Tabel 5: Distribusi pasien berdasarkan pekerjaan

\begin{tabular}{lll}
\hline Job characteristics & Frequency & Percentage \\
\hline Unemployment & 13 & 26 \\
Private Employees & 21 & 42 \\
Civil Servants & 3 & 6 \\
Entrepreneur & 13 & 26 \\
\hline
\end{tabular}

Table 6 below shows that the characteristics of patients based on length of HD, the highest number of patients is in the category of HD duration $<1 \mathrm{y}$ by 3 people (6\%), then in HD duration $1-3 \mathrm{y}$ as many as 16 people (32\%) and the most with HD duration $>3 \mathrm{y}$ as many as 31 people (62\%). 
Table 6: Distribution of patients based on HD duration

\begin{tabular}{lll}
\hline Long HD characteristics & Frequency & Percentage \\
\hline$<1 \mathrm{Y}$ & 3 & 6 \\
$1-3 \mathrm{Y}$ & 16 & 32 \\
$>3 \mathrm{Y}$ & 31 & 62 \\
\hline
\end{tabular}

\section{Quality of life of patients based on patient characteristics}

Table 7 shows the quality of life of HD patients based on characteristics. in the male sex as many as 19 people, who have a good quality of life as many as 1 person (5.3\%) and enough quality of life that is 17 people $(89.5 \%)$ and bad as much as 1 person $(5.3 \%)$. Whereas for women out of 31 people, 1 person had a good quality of life $(3.2 \%)$, moderate quality of life was 27 people $(87.1 \%)$ and those with poor quality of life were 3 people $(9.7 \%)$. this shows that men have better quality of life than women, although the difference is based on the correlation test is not significant ( $p=0.907)$.

The quality of life of HD patients is based on their level of education, in patients who have never taken formal education amounting to 1 person and have a good quality of life. at the elementary school level, all 6 patients $(100 \%)$ have sufficient quality of life. for the education level of junior high school, high school, S1, and S2/S3 most have a good quality of life that is $83.3 \%, 77.8 \%, 61.1 \%$ and $75 \%$. The quality of life of HD patients associated with the level of education, can be explained that the low level of education causes a lack of attention and knowledge about the importance of maintaining health, even though there is no statistically significant relationship $(\mathrm{p}=0.277)$

Quality of life of HD patients based on work, in patients who do not work as many as 13 people have good quality of life as many as 10 people $(76.9 \%)$, moderate quality of life 2 people $(15.4 \%)$ and bad 1 person $(7.7 \%)$, whereas in patients who work as a private employee as many as 21 people with good quality as many as 12 people $(57.1 \%)$ with enough quality of life $(38.1 \%)$ and bad as many as 1 person (4.8\%) and for civil servants and entrepreneurs also most have a good quality of life that is $100 \%$ and $53.8 \%$. The quality of life of HD patients who were assessed based on the place of work showed that work did not significantly affect the quality of life of hemodialysis patients at the Rasyida Kidney Hospital in Medan ( $\mathrm{p}=0.582)$.

Table 7: Quality of life of patients based on patient characteristics

\begin{tabular}{|c|c|c|c|c|c|c|c|}
\hline \multirow[t]{2}{*}{ Characteristics } & \multirow[t]{2}{*}{$\mathbf{n}$} & \multirow[t]{2}{*}{ (\%) } & \multicolumn{3}{|c|}{ Quality of life } & \multirow[t]{2}{*}{ Total (\%) } & \multirow[t]{2}{*}{ p value } \\
\hline & & & Good (\%) & Enough (\%) & Poor (\%) & & \\
\hline \multicolumn{8}{|l|}{ Sex } \\
\hline Man & 19 & 38 & $1(5.3)$ & 17 (89.5) & $1(5.3)$ & $19(100)$ & 0.907 \\
\hline Women & 31 & 62 & $1(3.2)$ & 27 (87.1) & $3(9.7)$ & 31 (100) & \\
\hline \multicolumn{8}{|l|}{ Education } \\
\hline No Education & 1 & 2 & $0(100)$ & $1(100)$ & $0(0)$ & $1(100)$ & 0.277 \\
\hline Elementary School & 6 & 12 & $0(0)$ & $5(100)$ & $1(16.7)$ & $6(100)$ & \\
\hline Junior High School & 12 & 24 & $0(0)$ & $10(83.3)$ & $2(16.7)$ & $12(100)$ & \\
\hline Senior High School & 9 & 18 & $1(11.1)$ & $8(88.9)$ & $0(0)$ & $9(100)$ & \\
\hline Bachelor & 22 & 44 & $1(4.5)$ & $20(90.9)$ & $1(4.5)$ & $22(100)$ & \\
\hline \multicolumn{8}{|l|}{ Job } \\
\hline Unemployment & 13 & 26 & $1(7.7)$ & $11(84.6)$ & $1(7.7)$ & $13(100)$ & 0.582 \\
\hline Private Employees & 21 & 42 & $0(0)$ & $18(85.7)$ & $3(14.3)$ & $21(100)$ & \\
\hline Civil Servants & 3 & 6 & $1(33.3)$ & $2(66.7)$ & $0(0)$ & $3(100)$ & \\
\hline Entrepreneur & 13 & 26 & $0(0)$ & $13(100)$ & $0(0)$ & $13(100)$ & \\
\hline
\end{tabular}

\section{Long relationship of hemodialysis with the quality of life of patients}

The quality of life of patients undergoing HD therapy in the Hemodialysis Unit of the Rasyida Kidney Special Hospital was largely classified as adequate, with most patients undergoing hemodialysis for a long time (31 patients). The longest patient undergoing HD in this study was 8 y (97 mo). It can be seen that the relationship between the length of hemodialysis and quality of life was analyzed using a bivariate correlation test and found a value ( $p$ $=0.259$ ) which means there is no significant relationship between the length of hemodialysis and the quality of life of patients with CKD undergoing HD therapy.

Tabel 8: Long relationship of hemodialysis with the quality of life of patients

\begin{tabular}{|c|c|c|c|c|c|c|c|c|c|c|}
\hline \multirow[t]{3}{*}{ No } & \multirow[t]{3}{*}{ Long HD } & \multicolumn{6}{|c|}{ Quality of life } & \multirow{2}{*}{\multicolumn{2}{|c|}{ Total }} & \multirow[t]{3}{*}{ p Value } \\
\hline & & \multicolumn{2}{|c|}{ Poor } & \multicolumn{2}{|c|}{ Enough } & \multicolumn{2}{|c|}{ Good } & & & \\
\hline & & $\mathbf{n}$ & $\%$ & $\mathbf{n}$ & $\%$ & $\mathbf{n}$ & $\%$ & $\mathbf{n}$ & $\%$ & \\
\hline 1 & $<1 \mathrm{Y}$ & 0 & 0 & 3 & 100 & 0 & 0 & 3 & 100 & 0,733 \\
\hline 2 & $1-3 \mathrm{Y}$ & 2 & 12,5 & 14 & 87,5 & 0 & 0 & 16 & 100 & \\
\hline 3 & $>3 \mathrm{Y}$ & 2 & 6,5 & 27 & 87,1 & 2 & 6,5 & 31 & 100 & \\
\hline
\end{tabular}

Relationship of hemodialysis complications with patient's quality of life

The most common complications in hemodialysis patients in this study were anemia (34\%) and itching (34\%), then hypertension/hypotension (18\%) and finally headache complications (14\%).
From table 9 below it can be seen that patients who experience hemodialysis complications in the form of anemia, itching, nausea and vomiting are lower in quality of life than patients who experience complications of hypertension/hypotension and headaches because $5.9 \%$ of patients have poor quality of life or 1 patient each. The picture is not significantly significant because the significance results obtained value ( $p=0.783)$. 
Table 9: Quality of life with hemodialysis complications category

\begin{tabular}{|c|c|c|c|c|c|}
\hline \multirow[t]{2}{*}{ Complications } & \multicolumn{3}{|c|}{ Life quality category } & \multirow{2}{*}{$\begin{array}{l}\text { Total } \\
\text { (Patient) }\end{array}$} & \multirow[t]{2}{*}{ p value } \\
\hline & Poor & Enough & Good & & \\
\hline Hypertension/hypotension & $0(0 \%)$ & $8(88.9 \%)$ & $1(11.1 \%)$ & $9(18 \%)$ & 0,783 \\
\hline Anemia & $1(5.9 \%)$ & $15(88.2 \%)$ & $1(5.9 \%)$ & $17(34 \%)$ & \\
\hline Headache & $0(0 \%)$ & $7(100 \%)$ & $0(0 \%)$ & $7(14 \%)$ & \\
\hline Itching, nausea, vomiting & $1(5.9 \%)$ & $1694.1 \%)$ & $0(0 \%)$ & $17(34 \%)$ & \\
\hline
\end{tabular}

The effect of giving therapy with pharmaceutical care on the quality of life of patients

The effect of providing therapy with pharmaceutical care on the quality of life of patients with renal failure who experience complications while undergoing hemodialysis shows that from each of the 50 patients there was an increase in the quality of life before giving therapy with pharmaceutical care (48.12) with after administration of therapy accompanied by pharmaceutical care (48) 50.16).

The percentage of quality of life of patients experiencing complications during hemodialysis at the Rasyida Kidney Hospital in Medan showed that the majority of patients (44 patients/88\%) had adequate quality of life. the quality of life includes quality in physical, psychological health, social relations and the environment.

The results of different test scores of the average quality of life of HD patients before and after being given therapy and pharmaceutical care using the Wilcoxon test showed a significant improvement in the quality of life of patients experiencing complications during hemodialysis with the administration of therapy accompanied by pharmaceutical care $(p=0.009)$, $p$ This shows that there is a significant effect of providing therapy along with pharmaceutical care to the quality of life of patients.

This proves that the administration of therapy accompanied by pharmaceutical care is effective in improving the quality of life of patients with hemodialysis who experience complications.

Table 10: Changes in quality of life before and after pharmacy therapy and care.

\begin{tabular}{lll}
\hline Type & N & Average quality of life \\
\hline Before therapy and pharmaceutical care & 50 & $48.12 \pm 5,98$ \\
After therapy and pharmaceutical care & 50 & $50.16 \pm 6,22$ \\
\hline
\end{tabular}

Table 11: Percentage of quality of life of patients experiencing complications during hemodialysis

\begin{tabular}{lllll}
\hline & & Frequency & Percentage & Total percentage \\
\hline Quality of life & Poor & 2 & 4.0 & 4.0 \\
& Enough & 44 & 88.0 & 92.0 \\
& Good & 4 & 8.0 & 100.0 \\
\hline & Total & 50 & 100.0 & \\
\hline
\end{tabular}

Table 12: Results of different test scores of average quality of life of HD patients before and after pharmacy treatment and care

\begin{tabular}{ll}
\hline Group & mean \pm SD \\
\hline Before therapy and pharmaceutical care & $50 \pm 6,2$ \\
After therapy and pharmaceutical care & 0,009 \\
\hline
\end{tabular}

\section{DISCUSSION}

In CKD patients who undergo hemodialysis are often reported to have decreased quality of life, both in terms of physical, mental, social and environmental. The quality of life of CKD patients undergoing $\mathrm{HD}$ is of paramedical interest, because essentially the purpose of HD is to maintain the quality of life of patients [11].

CKD patients occur a decrease in quality of life which includes physical, mental and social well-being [12]. World Health Organization Quality of Life stated that quality of life is an individual's perception of the abilities, limitations, symptoms and psychosocial nature of his life in the context of culture and value systems to carry out their roles and functions [13].

In CKD patients there is a decrease in physical conditions such as body weight and mobility abilities. CKD patients must undergo hemodialysis with regular scheduling from 1 (one) to 3 (three) times a week, this can affect their social and psychological relationships indirectly. In connection with these problems, the role of pharmacists as health workers is needed to maintain and improve the quality of life of CKD patients.

This study shows that most patients have moderate quality of life, but each respondent has a different value. This may also depend on the respondents' perceptions and the severity of the disease, also because CKD cannot be cured. This is in line with other studies which state that HD patients tend to have a dependency on hemodialysis therapy [14].

Besides the various physical complaints complained of by patients depending on the severity of the disease and the complications that accompany that are not the same between one patient with another patient. This is consistent with the theory that HD patients will feel discomfort, tightness, edema, chest pain, nausea or even vomiting, and muscle cramps that cause severe pain [15].

The highest age range is found at the age of 51-60 y which is equal to $36 \%$. This situation is in accordance with the general description of CKD patients undergoing hemodialysis in Indonesia, as also reported by IRR in 2011 as many as $89 \%$ of CKD patients undergoing hemodialysis aged 35-70 y with the most age group of 45-54 y ie $27 \%[16]$.

Decreased kidney function is a normal process with increasing human age. Increasing human age shows a progressive decrease in Glomerular Filtration Rate (GFR) and Renal Blood Flow (RBF). The decrease occurred around $8 \mathrm{ml} / \mathrm{min} / 1.73 \mathrm{~m} 2$ per decade since the age of $40 \mathrm{y}$ [17].

Based on the Indonesian Renal Registry (IRR), the incidence of chronic kidney failure that occurs in Indonesia is higher in men 0.3 
percent) than women (0.2 percent) [16]. Other studies have found that the prevalence of kidney disease in men and women is $10.6 \%$ and $7.1 \%$ [18].

This study shows there is no relationship between the level of education with the incidence of CKD in patients with hypertension in Indonesia. This is in line with the results of previous studies, which prove that there is no significant relationship between the level of education with the incidence of CKD $(p=0.63)$ [19].

This study shows that there is no relationship between working and non-working patients with CKD events. This study is in line with the results of previous studies, which prove that there is no meaningful relationship between work and the occurrence of CKD $(p=0.42)$ [19].

This study shows that the majority of patients have more than $1 \mathrm{y}$ underwent hemodialysis at the Rasyida Kidney Hospital in Medan. This is in line with research conducted by Salawati L, that $34 \%$ of patients undergo HD for 3 mo to $1 \mathrm{y}$ and $66 \%$ of patients undergo HD for more than $1 \mathrm{y}$ [20].

The quality of life of HD patients by sex, in men have a better quality of life than women. This study is in line with previous studies which found that there was no statistically significant relationship between sex and quality of life [21].

The quality of life of HD patients which is associated with the level of education, can be explained that the low education causes a lack of attention and knowledge about the importance of maintaining health. Low education results in socioeconomic status, especially low income so that the subject does not seek obstruction due to lack of funds. Quality of life owned by patients with low education tends to be worse than patients with high education [22].

The quality of life of HD patients who were assessed based on the workplace showed that work did not significantly affect the quality of life of hemodialysis patients at the Rasyida Kidney Hospital in Medan. These results contradict the results of previous studies that work affects the quality of life of patients [23].

This study shows that there is no significant relationship between the length of hemodialysis and the quality of life of patients with CKD undergoing HD therapy. These results are in line with previous research which states that there is no significant relationship between the length of undergoing hemodialysis and the quality of life of patients [24]. Other studies have shown no relationship between length of HD and the quality of life of patients [25].

The most common complications in hemodialysis patients in this study were anemia (34\%) and itching (34\%), then hypertension/hypotension (18\%) and finally headache complications (14\%). Other studies have found that common complications include nausea, vomiting with an incidence of 5\%$15 \%$, headaches with an incidence of 5\%-10\% and itching with an incidence of $5 \%-10 \%$ [26]. Intradialysis hypotension is also one of the most common complications in hemodialysis patients, accounting for $20-30 \%$ of the complications of hemodialysis [27].

This study proves that the administration of therapy accompanied by pharmaceutical care is effective in improving the quality of life of hemodialysis patients who are experiencing complications. This study is in line with previous studies which found that the impact of patient counseling on quality of life in hemodialysis patients was found to be very effective [28]. Providing Pharmaceutical Care can control compliance with the use of drugs and the right diet can also ultimately improve the quality of life of patients.

\section{CONCLUSION}

Patients undergoing long-term hemodialysis often experience hemodialysis complications that affect the quality of life of patients as measured using WHOQOL, providing therapy with pharmaceutical care significantly improves the quality of life of hemodialysis patients.

\section{ANKNOWLEDGMENT}

The author thanks the Faculty of Pharmacy, University of Sumatera Utara for all support for this research.

\section{AUTHORS CONTRIBUTIONS}

All authors contributed to the entire process of writing this article.

\section{CONFLICT OF INTERESTS}

Declared none

\section{REFERENCES}

1. Kaze FF, Ashuntantang G, Kengne AP. Acute hemodialysis complication in end-stage renal disease patients: the burden and implication for the under-resourced Sub-Saharan African Health system. Hemosial Int 2012;16:526-31.

2. Landry DW, Oliver JA. Blood pressure instability during hemodialysis. Kid Int 2006;69:1710-1.

3. Tatsuya S, Tsubakihara Y, Fujii M, Imai E. Hemodialysisassociated hypotension as an independent risk factor for twoyear mortality in hemodialysis patients. Kidney Int 2004;66:1212-20.

4. Agustriadi O. Hubungan antara perubahan volume darah relatif dan episode hipotensi intradialitik selama hemodialisis pada gagal ginjal kronik (karya akhir). Denpasar: UniversitasUdayana; 2009.

5. Weisbord SD, Fried LF, Arnold RM, Fine MJ, Levenson DJ, Peterson RA, et al. Prevalence, severity, and importance of physical 91 and emotional symptoms in chronic hemodialysis patients. J Am Soc Nephrol 2005;16:2487-94.

6. Burton JO, Korsheed S, Grundy BJ, McIntyre CW. Hemodialysisinduced left ventricular dysfunction is associated with an increase in ventricular arrhythmias. Ren Fail 2008;7:701-9.

7. Herzog CA, Mangrum JM, Passman R. Sudden cardiac death and dialysis patients. Semin Dial 2008;21:300-7.

8. Kobrin SM, Berns JS. Quinine--a tonic too bitter for hemodialysis-associated muscle cramps? Semin Dial 2007:20:396-401.

9. Jesus AC, Oliveira HA, Paixao MO, Fraga TP, Barreto FJ, Valenca MM. Clinical description of hemodialysis headache in end-stage renal disease patients. Arq Neuropsiquiatr 2009;7:978-81.

10. Budiarto dan Anggraeni. Pengantar Epidemiologi, Edisi 2. Jakarta. EGC; 2002.

11. Rahman ARA, Rudiansyah M, Triawanti. Hubungan antara adekuasi hemodialisis dan kualitas hidup pasien di RSUD Ulin Banjarmasin; 2013. Available from: http://unnes.ac.id/. [Last accessed on 07 Nov 2013]

12. Lacson EJR, Xu J, Lin SF, Dean SG, Lazarus JM, Hakim RM. A comparasion of SF-36 and SF-12 composite score and subsequent hospitalization and mortality risks in long-term dialysis patient. Clin Sci USA; 2010.

13. World Health Organization. Management of substance abuse: WHO Quality of Life-BREF (WHOQOL-BREF); 2016. Available from: http://www/who.int. [Last accessed on 07 Nov 2013]

14. Suhud M. Cuci darah demi kualitas hidup, Kompas Syb; 2005.

15. Brunner and Suddarth. Buku Ajar Keperawatan Medikal Bedah, Ed 8. Jakarta: EGC; 2002.

16. Indonesian Renal Registry (IRR). Report of Indonesian Renal Registry 2011. PerhimpunanNefrologi Indonesia (PERNEFRI); 2013.

17. Weinstein JR, Anderson S. The aging kidney: physiological changes. Nih Public Access 2010;17:302-7.

18. Bakirci T, Sasak G, Ozturk S, Akcay S, Sezer S, Maberal M. Pleural effusion in long term hemodialysis patients. Transplantation Proceeding 2007;39:889-91.

19. Eva Sulistiowati, Sri Idaiani. Faktor risiko penyakit ginjal kronik berdasarkan analisis cross-sectional data awal studi kohort penyakit tidak menular penduduk usia 25-65 tahun di kelurahan kebon kalapa. Buletin Penelitian Kesehatan 2015;1:14-7.

20. Salawati L. Analisis lama hemodialisis dengan status gizi penderita penyakit ginjal kronik. Jurnal Kedokteran Syiah Kuala 2016;16:64-8.

21. Sutikno E. Hubungan fungsi keluarga dengan kualitas hidup lansia. Tesis, Surakarta: Universitas Sebelas Maret; 2011.

22. Wangsarahardja K. Kebutuhan pelayanan kesehatan gigi dan mulut pada masyarakat berpenghasilan rendah. Sci J Dentistry 2007;22:90-9. 
23. Wig NL, Pal H, Ahuja V, Mittal C, Mohan, Agarwal S. The impact of HIV/AIDS on the quality of life: a cross sectional study in North India. Indian J Med Sci 2006;60:3-11.

24. Rahman, Moch TSA, Kaunang, Theresia MD, Elim C. Hubungan antara lama menjalani hemodialisa dengan kualitas hidup pasien yang menjalani hemodialisa di unit hemodialisa RSUP. Prof. Dr. R. D. Kandou Manado. J e-Clinic (eCl); 2016. p. 4.

25. Puspita DS. Hubungan lama hemodialisis dengan pasien gagal ginjal di RS PKU Muhammadiyah Yogyakarta (dissertation). Ilmu Keperawatan. [Yogyakarta]: Sekolah Tinggi Ilmu Kesehatan 'Aisyiyah; 2015.
26. Jesus AC, Oliveira HA, Paixao MO, Fraga TP, Barreto FJ, Valença MM. Clinical description of hemodialysis headache in end-stage renal disease patients. Arq Neuropsiquiatr 2009;7:978-81.

27. KDOQI Clinical Practice Guidelines for Cardiovascular Disease in Dialysis patients: NKF KDOQI Guidelines, National Kidney Foundation Inc; 2015.

28. Thomas D, Joseph J, Francis B, Mohanta GP. Effect of patient counseling on quality of life of hemodialysis patients in India. Pharm Pract (Granada) 2009;7:181-4. 